\title{
The impact of understanding learners and techno-pedagogical competency on effective learning environments by designing the instructional process
}

\author{
Ragıp Terzi \\ Harran University, Faculty of Education, Şanlıurfa, Turkey, terziragip@harran.edu.tr
}

Check for updates

ABSTRACT This study aims to understand prospective teachers' (PTs) preparedness to teach before they actually start working in the profession. In particular, the causal effects of "understanding the learner" and "techno-pedagogical competency" on "forming effective learning environments" by "designing the instructional process" were investigated. Structural equation modeling was carried out to estimate the effects of these variables on effective learning environments. A cross-sectional survey design was used with 314 PTs who were studying in a state university in Turkey in the 2019-2020 spring semester. For the purpose of this study, Preparedness to Teach scale was used to obtain the data after investigating the scale for validity and reliability properties. The results suggested that understanding the learner had both direct and indirect effects on forming effective learning environments. That is, the better PTs could understand the learner, the more appropriately they could design the instructional process and, ultimately, form an effective learning environment. However, techno-pedagogical competency had only indirect impacts on forming an effective learning environment. This finding suggests that the higher-competency PTs had in techno-pedagogy, the more effectively they could establish a learning environment by properly designing the instructional process.

Keywords: Measurement and evaluation in education, Designing instructional process, Effective learning environments, Structural equation modeling, Techno-pedagogical competency, Understanding learners

\section{Öğretim sürecini tasarlayarak öğrenenleri anlama ve tekno- pedagojik yeterliğin etkili öğrenme ortamları üzerinde etkisi}

ÖZ Bu çalışmanın amacı, öğretmen adaylarının öğretmenlik mesleğine başlamadan önce öğretmeye hazır olmalarını anlamaktır. Özellikle, "öğretim sürecini tasarlamak" aracılığıyla "öğreneni anlama" ve "tekno-pedagojik yeterliğin" "etkili öğrenme ortamları oluşturma" üzerindeki nedensel etkileri araştırılmıştır. Bu değişkenlerin etkili öğrenme ortamları üzerindeki etkilerini yordamak için yapısal eşitlik modellemesi uygulanmıştır. Türkiye'deki bir devlet üniversitesinde 2019-2020 bahar döneminde eğitim gören 314 öğretmen adayı ile kesitsel ölçek tasarımı kullanılmıştır. Bu çalışmanın amacı doğrultusunda, Öğretmenliğe Hazır Olma ölçeği kullanılarak veriler toplanmış olup, ölçeğin geçerlik ve güvenirlik özellikleri incelenmiştir. Sonuçlar öğreneni anlama'nın etkili öğrenme ortamları oluşturma üzerinde hem doğrudan hem de dolaylı etkileri olduğunu tavsiye etmektedir. Yani, öğretmen adaylarının öğreneni ne kadar iyi anlarsa, öğretim sürecini o kadar uygun bir şekilde tasarlayabilecek ve nihayetinde etkili bir öğrenme ortamı oluşturabilecektir. Ancak, tekno-pedagojik yeterliğin etkili öğrenme ortamları olușturma üzerinde sadece dolaylı etkileri olduğu saptanmıștır. Bu bulgu, tekno-pedagojide daha yüksek yetkinliğe sahip öğretmen adaylarının öğretim sürecini uygun bir şekilde tasarlayarak daha etkili bir öğrenme ortamı oluşturabileceklerini göstermektedir.

Anahtar Ĕgitimde ölçme ve değerlendirme, Etkili öğrenme ortamı, Öğreneni anlama, Öğretim süreci Sözcükler: tasarımı, Tekno-pedagojik yeterlik, Yapısal eşitlik modellemesi 


\section{INTRODUCTION}

It has always been one of the most critical emerging demands of all school stakeholders that the quality of the teachers and the primary function of schools should be at the center of determining high standards for student achievement (Bush, 2008; Darling-Hammond, 2006). Many studies have shown that the quality of a school's teachers is the most influential variable regarding student achievement among other educational variables (Hanushek, 2011; Hattie, 2009; Nye, Konstantopoulos, \& Hedges, 2004; Rowan, Correnti, \& Miller, 2002). These results have led to the examination of preparedness of both prospective teachers (PTs) and in-service teachers for classroom teaching. In particular, the transition for PTs to the profession has some uncertainty since they can find teaching more challenging than they expect (Joiner \& Edwards, 2008; Knight, \& Moore, 2012; Pillen, Beijaard, \& den Brok, 2013). Difficulties PTs encounter before starting their profession are related to two sources: either they do not have realistic notions of teaching and their students, or other stakeholders do not have realistic expectations of them (Hagger, Mutton, \& Bird, 2011).

In dealing with the aforementioned challenges, as well as others, some well-rounded skills PTs should have before starting to teach were described by the National Council for Accreditation of Teacher Education (NCATE, 2008). Among all, essential skills relevant to this present study are: having strong content knowledge; presenting content properly; enriching courses with real-world examples; using appropriate technology; understanding students' prejudgments; designing instructional environments based on experience and research; relating concepts to students' experiences; practicing real-world issues in teaching; devoting to enhancing school success; evaluating the achievement levels of students; adjusting one's teaching strategy based on students' ability to learn; involving colleagues, parents, and other stakeholders; and providing complementary learning atmosphere (Eret, 2013; NCATE, 2008).

In this regard, forming effective learning environments is one of the most crucial components of effective teaching. However, it could occur if the students' needs could be taken care of from specific points. These points consist of properly understanding the learner (Lane \& Sharp, 2014) and adequately demonstrating competency in techno-pedagogy (Chai, Ng, Li, Hong, \& Koh, 2013) by appropriately designing the instructional process (Morrison, Ross, Morrison, \& Kalman, 2019). Thus, this study aims to understand to what extent effective learning environments can be formed by understanding the learner and demonstrating competency in techno-pedagogy in a way explained by designing the instructional process. For the purpose, the rest of the paper will introduce the theoretical framework for the study in the next section, followed by methodology, results, and discussion and conclusion sections, respectively.

\section{Theoretical Framework}

Given the skills expected from PTs for their own professional teaching development, forming effective learning environments could be considered their ultimate goal, based on the integration of understanding the learner and techno-pedagogical competency by designing the instructional process.

\section{Understanding the learner}

Understanding learners plays a critical role in designing the instructional process and forming effective learning environments. Cook-Sather states that "students should help shape rather than simply be shaped by educational policies and practices" (2003, p. 22). Teachers should understand the prejudgments of students and evaluate the level of their preparedness before starting teaching activities (NCATE, 2008). Relating to having a firm grasp of their subject matter, knowledge, and skills, teachers should have the ability to relate all learning activities to students' experiences in a way that enables them to learn (Eret, 2013). The formative assessment, for example, can be used to investigate the learner' achievement levels such that teachers need to set expected learning performance to monitor whether students have mastered 
the required skills. Therefore, students' active involvement in learning activities is necessary to build effective conversion pedagogy for empowering the students (Jones, Olds, \& Lisciandro, 2016). In addition to being responsible for students' learning and achievement (Darling-Hammond, 2006), teachers have the most influential impacts on students' social, as well as mental and emotional development (Bandura, 1969). For instance, if teachers abstain from indicating student mistakes, they can establish a complementary classroom environment (Senior, 2006). There are also three crucial areas for providing students with successful pedagogies: understanding the difficulties of the learner, establishing desire for learning through collaborative classroom environments, and the availability of a permissive pedagogy (Lane \& Sharp, 2014). Therefore, teachers should properly design the instructional process based on understanding the learner and their needs so that effective learning environments can be formed.

\section{Techno-pedagogical competency}

The concept of techno-pedagogical competency defined by Niess (2005) is that planning, applying, and assessing the educational processes based on technology and pedagogy can improve teaching effectiveness. A number of studies have been conducted to develop teacher competency by connecting the construct of technology, pedagogy, and content knowledge for effective teaching (TPACK; Chai et al., 2013; Harris, Mishra, \& Koehler, 2009; Lin, Tsai, Chai, \& Lee, 2013; Mishra \& Koehler, 2006; Schmidt, Baran, Thompson, Mishra, Koehler, \& Shin, 2009). The TPACK concept has recently become a prominent framework used in educational technology (Hew, Lan, Tang, Jia, \& Lo, 2019). In other studies, technology-integrated educational activities have been discussed extensively (Compton \& Harwood, 2003; Hofer \& Swan, 2008; Koehler, Mishra, \& Yahya, 2007; Liao, 2007). Since the effective use of information technology is an essential ability teachers are required to have in the $21^{\text {st }}$ century (Eret, 2013), the use of technology in education can help students obtain high-level skills (Hofer \& Swan, 2008; Koehler et al., 2007). However, some studies have discussed that teachers are not comfortable with integrating educational technologies into classrooms for effective teaching (Bang \& Luft, 2013; Brown \& Englehardt, 2017; Kushner Benson, Ward, \& Liang, 2015). In this regard, prospective teachers should be sufficiently prepared to accommodate technology into classrooms in a component way (Chen, Looi, \& Chen, 2009; Inan \& Lowther, 2010). Web 2.0 tools, Kahoot, Padlet, and Edmodo are some applications of the TPACK concept that can be applied for teaching purposes. Although not all schools can provide these types of technology integrated materials, teachers still need to effectively carry out educational activities by using convenient technological equipments (Koh, Chai, \& Tsai, 2013; Kumar, Rose, \& D’Silva, 2008). Because of its importance, Hofer and Swan (2008) suggest that both in-service teachers and PTs should obtain the necessary skills and knowledge by using technology in teaching. Many activities, such as increasing students' interest and learning; supporting research and analyses; assessing and tracking student achievement; communicating with students, colleagues, and parents; and enhancing group collaboration and teamwork, require the use of technology in education. In light of these studies, we could state that teachers with a higher level of technopedagogical competency can successfully form more effective learning environments by properly designing the instructional process given the developments of information technology in the $21^{\text {st }}$ century.

\section{Designing the instructional process}

Instructional design process is another vital component of forming best possible learning environments for students. In addition to being economic, instructional design can make the learning environment more effective and efficient and less difficult (Morrison et al., 2019). When teachers involve students to participate in the learning process, active learning can occur based on "unmissable" lectures with "participative and engaging, as well as challenging and thought-provoking" activities (Revell \& Wainwright, 2009, p.212). Some examples of these activities are: using both effective verbal and nonverbal communication strategies to have students learn content properly, stimulating courses with examples from the real world, practicing real-world issues in teaching, guiding students to learn how to approach solving problems with critical thinking, helping students interpret notions with diverse perspectives, teaching students how to evaluate their own learning, and ultimately, providing 
instructional environments based on experience and research (Darling-Hammond, Chung, \& Frelow, 2002; NCATE, 2008). If students are given opportunities to actively participate in classroom activities and exercise various learning alternatives, teachers and students can co-design a compelling and appealing classroom environment (Schunk, Pintrich, \& Meece, 2008). Nonetheless, because instruction does not directly affect student learning, the teaching activities do not probably reach its goals unless the notions of instructional designers as well as teachers serve to students' understanding (Doyle, 1977). Therefore, PTs in teachers' training programs should gain the skills of properly understanding the learners and techno-pedagogical competency to design the instructional process. TPACK, which combines technology, pedagogy, and content knowledge, is a comprehensive concept that reflects PTs' experiences of integrating technology into their teaching activities. Therefore, all these activities as a part of designing the instructional process can be put into practices based on understanding learners and competency in techno-pedagogy, which can ultimately lead to building effective learning environments.

\section{Forming effective learning environments}

In designing the instructional process, the classroom atmosphere, a crucial factor in an effective classroom, provides teachers and students with healthy relationships, encouragement, and determination among students, and promotes teaching and learning processes (Senior, 2006). Therefore, the classroom environment should be designed to promote social development and group responsibility for effective learning environments. Moreover, forming effective learning environments requires involving all stakeholders in educational activities, designing supportive learning environments, and ultimately devoting one to enhance school achievement (NCATE, 2008). Nevertheless, caring teachers must be interested in understanding students' backgrounds that influence learning, identifying and addressing students' special learning needs, using teaching techniques for various instructional goals, and providing students with individual and cooperative learning environments (Darling-Hammond et al., 2002). Moreover, effectiveness in classroom management and instructional strategies, as well as competency in using educational technology, is a part of preparedness for PTs (Imbimbo \& Silvernail, 1999). Furthermore, effective classroom management that encourages learning to happen is: "a multi-faceted skill set encompassing the structure and atmosphere of the classroom space, the instructional choices of the teacher, the pedagogical and practical knowledge driving these decisions, and the stream of interaction and exchange occurring inside (and outside) the classroom" (Wolff, van den Bogert, Jarodzka, \& Boshuizen, 2015, p. 71).

\section{Research Questions}

The primary purpose of the research presented in this article is to investigate the hypothesized model that the direct and indirect effects of understanding the learner and techno-pedagogical competency on forming effective learning environments can be explained by designing the instructional process. The hypothesized model for this study is presented in Figure 1. In particular, the research questions addressing this objective are as follows:

(1) To what extent understanding the learner can have direct and indirect effects on forming effective learning environments by designing the instructional process?

(2) To what extent techno-pedagogical competency can have direct and indirect effects on forming effective learning environments by designing the instructional process? 


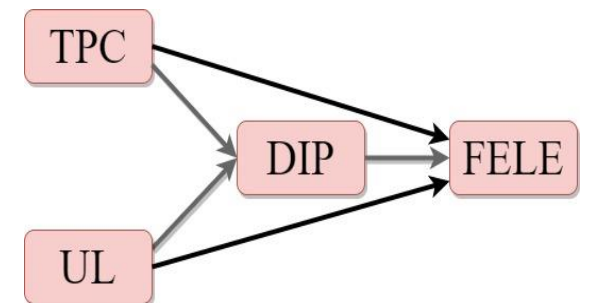

Figure 1. Hypothesized structural equation model

\section{METHODOLOGY}

In this study, data were collected by the Preparedness to Teach Scale and analyzed by Structural Equation Modeling (SEM), which is a combination of exploratory factor and multiple regression analyses (Ullman, 2001). For this study, the causal relationship of "techno-pedagogical competency (TPC)" and "understanding the learner (UL)" by "designing the instructional process (DIP)" on "forming an effective learning environment (FELE)" was investigated.

\section{Participants}

The population of this study consists of PTs in a state university in Turkey who were studying in the 2019-2020 academic year. Note that the ethical approval for this study was obtained from the Social and Behavioral Research Ethics Committee at Harran University. The number of participants was 314; $22.9 \%(N=72)$ male and $77.1 \%(N=242)$ female. The distribution of the $314 \mathrm{PTs}, 39.8 \%(N=125)$ from the faculty of education, $35.0 \%(N=110)$ from a pedagogical certificate program, and $25.2 \%(N$ $=79$ ) from the faculty of theology shows the diversity of the students. Participants were informed about the purpose of the study and solicited to involve themselves voluntarily through an online survey form.

\section{Measurement Tool: The Preparedness to Teach Scale}

The scale of Preparedness to Teach first was administered by the collaborations of New Visions for Public Schools and the National Commission on Teaching and America's Future in 1998. Among the 40 items originally developed, the scale was finalized with 36 items in five dimensions (Silvernail, 1998). Later, Darling-Hammond et al. (2002) administered the scale to 2,956 teachers with four or fewer years of teaching experience to investigate their readiness to teach. In 2017, Yildirim and Kalman adapted the scale into Turkish and showed a significantly strong and positive correlation between the English and Turkish versions of the scale $(r=.81, p<.001)$. Furthermore, they reported that the Cronbach's Alpha reliability coefficient of the scale was .923 in addition to the construct, criterion, face, and content validity of the scale. Based on exploratory factor analysis (EFA) and confirmatory factor analysis (CFA) for construct validity, the scale was further finalized by 20 items with four subscales: "forming an effective learning environment (FELE)," "designing the instructional process (DIP)," "techno-pedagogical competency (TPC)," and "understanding the learner (UL)" (Yildirim \& Kalman, 2017).

In the present study, the scale was administered to PTs studying in a university, and 336 PTs have responded. In the beginning, SPSS version 22.0 was used to impute missing responses via the ExpectedMaximization algorithm (IBM Corp, 2013). After handling the missing data and cleaning the data with outliers, analyses were further carried out with 314 responses. Furthermore, other assumptions (i.e., multivariate normality, unidimensionality, and multicollinearity) that underlie the application of SEM were investigated. For the normality assumption, skewness and kurtosis values for each dimension were investigated based on the sample size of 314. The null hypotheses of normal distribution for each dimension were accepted because absolute values of skewness and kurtosis were lower than 2 (West, Finch, and Curran, 1995). According to factor analyses conducted by Silvernail (1998), Yildirim and 
Kalman (2017), and the present study, the unidimensionality of each dimension of the scale was observed. Furthermore, the multicollinearity assumption was tested with Variance Inflation Factor (VIF). Given the VIF values of UL (2.31), TPC (2.71), and DIP (3.47) being lower than 10 (Kline, 2011 ), this assumption was met. Since all the assumptions were satisfied, the rest of the analyses can be carried out.

Next, CFA was implemented for construct validity so that how well latent variables can be explained by the items was investigated (Suhr, 2006). CFA was carried out via Mplus (Muthén \& Muthén, 2007). Due to the large number of degrees of freedom, the chi-square value was found significant $\left(\chi^{2}=546.56\right.$, $d f=160, p<0.05$ ). However, values of the Tucker-Lewis index (TLI; Tucker \& Lewis, 1973), the comparative fit index (CFI; Bentler, 1990), the root mean square error of approximation (RMSEA), and the standardized root mean square residual (SRMR) were $.92, .93, .087$, and 0.037 , respectively. These fit indices showed a good fit of the model to the data (Bentler \& Hu, 1995; Browne \& Cudeck, 1992; Kline, 2011).

Nevertheless, the Cronbach's Alpha reliability coefficient was .97 for the whole scale (20 items), .86 for the UL ( 3 items), .92 for the FELE ( 6 items), .93 for the DIP ( 6 items), and . 88 for the TPC (5 items). Based on these reliability results, strong evidence of consistency in the PTs' responses to the survey items was observed.

\section{RESULTS}

In this section of the paper, the SEM results for the casual relationship of techno-pedagogical competency (TPC) and understanding the learner (UL) by designing the instructional process (DIP) on forming an effective learning environment (FELE) were discussed. Mplus (Muthén \& Muthén, 2007) was also used for SEM. Similar to CFA, a large number of degrees of freedom led to a statistically significant chi-square value $\left(\chi^{2}=548.643, d f=161, p<0.05\right)$. Nevertheless, the values of the TLI, the CFI, the RMSEA, and the SRMR, .92, .93, .087, and 0.037, respectively, showed a good fit of the model to the data (Bentler \& Hu, 1995; Browne \& Cudeck, 1992; Kline, 2011).

Furthermore, descriptive statistics of the mean, standard deviation, and correlations of the indicators (i.e., items) used in the model were reported in Table 1 (see Appendix). The mean values of indicators were relatively high, based on the five-point Likert-type scale, ranging from 3.58 ( $\mathrm{SD}=1.16$ ) for item 4 to $3.94(\mathrm{SD}=1.05)$ for item 14 . The correlations among the indicators were positive and statistically significant at the 0.001 level, which ranged from 0.305 to 0.784 . The lowest correlation was observed between i1 and i19; the former one is under the FELE dimension, and the latter is under the TPC dimension. The highest correlation was observed between $\mathrm{i} 6$ and i7, which are under the TPC dimension.

Table 2.

Standardized Estimates of SEM for Forming Effective Learning Environments

\begin{tabular}{llccccc}
\hline & & \multirow{2}{*}{ Estimate } & SE & $p$ & \multicolumn{2}{c}{ 95\% Bootstrap CI } \\
\cline { 5 - 7 } & & & & Lower & Upper \\
\multirow{5}{*}{ Direct Effects } & TPC $\rightarrow$ FELE & 0.768 & 0.068 & 0.000 & & \\
& $\mathrm{UL} \rightarrow$ DIP & 0.692 & 0.061 & 0.000 & & \\
\multirow{5}{*}{ Total Indirect Effects } & 0.298 & 0.065 & 0.000 & & \\
Total Effects & $\mathrm{UL} \rightarrow$ FELE & 0.209 & 0.101 & 0.039 & 0.010 & 0.408 \\
& $\mathrm{TPC} \rightarrow$ FELE & 0.532 & 0.104 & 0.000 & 0.333 & 0.730 \\
& $\mathrm{UL} \rightarrow$ FELE & 0.229 & 0.091 & 0.012 & 0.051 & 0.408 \\
& $\mathrm{UL} \rightarrow$ FELE & 0.438 & 0.102 & 0.000 & 0.238 & 0.639 \\
\hline
\end{tabular}

Note. Results are based 1,000 bootstrapped samples. UL: understanding the learner; TPC: techno-pedagogical competency; DIP: designing the instructional process; FELE: forming an effective learning environment. 
The hypothesized SEM was tested with the specified direct and indirect effects of "understanding the learner" and "techno-pedagogical competency" by "designing the instructional process" on "forming an effective learning environment." When the direct and indirect effects of TPC on FELE was modeled, TPC did not show statistically significant indirect $(\beta=0.399, p=.061)$ and direct $(\beta=0.170, p=.455)$ effects on FELE. After removing the direct effect of TPC on FELE, the model was updated. Table 2 also displays the standardized direct and indirect estimates of UL and TPC on FELE by DIP. Note that, the effects of UL and TPC on FELE by DIP will not refer to mediation, but rather to the indirect effects, because the variables in the model were concurrently measured (Kline, 2011). Given the updated model presented in Figure 2, 91\% of the variance in FELE can be explained by all the measured variables specified in the model.

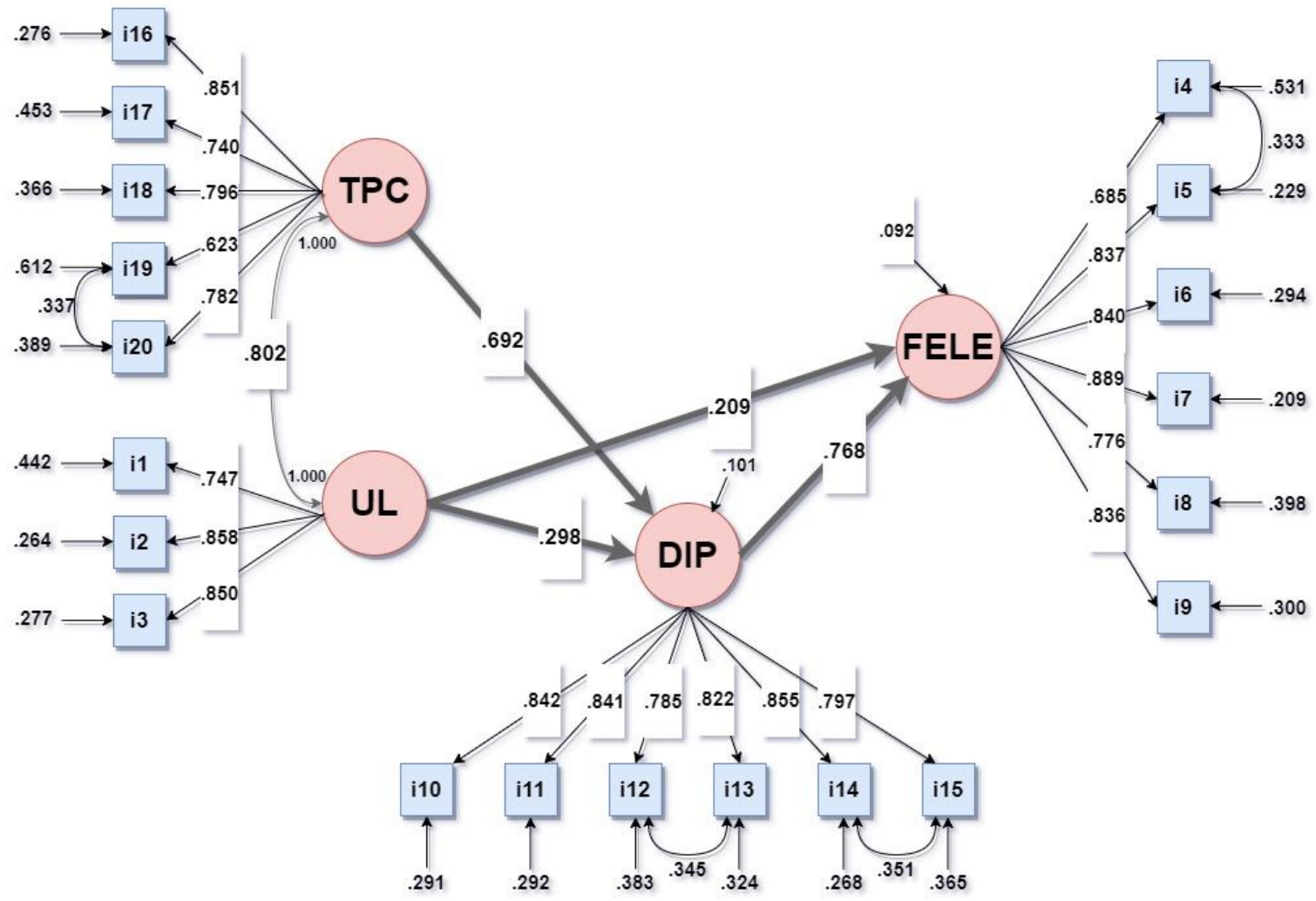

Figure 2. Structural Equation Model for Forming Effective Learning Environments

Since standardized and unstandardized estimates show similar results, only standardized estimates were discussed. First, UL provided statistically significant indirect $(\beta=0.229, p=0.012)$ and $\operatorname{direct}(\beta=$ $0.209, p=0.039)$ effects on FELE. This complied with the significant total effect of UL on FELE $(\beta=$ $0.438, p<0.001)$. That is, the better the PTs could understand the learner, the more effectively they could design the instructional process and ultimately form an effective learning environment. Second, UL had significant effects on DIP $(\beta=0.298, p<0.001)$, in that PTs could properly design the instructional process by better understanding the learner. Third, TPC suggested statistically significant indirect effects on FELE through the intervening variable DIP $(\beta=0.532, p<0.001)$. The positive direction of the relationship means that the higher competency PTs had in techno-pedagogy, the more effectively they could build a learning environment by designing the instructional process. Last, TPC demonstrated a statistically significant positive relationship with $\operatorname{DIP}(\beta=0.692, p<0.001)$, indicating that when PTs had a higher level of competency in techno-pedagogy, they became more confident in effectively designing the instructional process. 


\section{DISCUSSION AND CONCLUSION}

The main goal of this study was to investigate the direct and indirect effects of understanding the learner and techno-pedagogical competency on forming effective learning environments that can be explained by designing the instructional process. In particular, the direct and indirect effects of understanding the learner that can form effective learning environments by designing the instructional process were investigated. Additionally, the direct and indirect effects of techno-pedagogical competency that can form effective learning environments by designing the instructional process were explored. For these purposes, the scale of Preparedness to Teach was used (Darling-Hammond et al., 2002; Silvernail, 1998), which was recently adapted into Turkish by Yildirim and Kalman (2017). Even though the original scale had five dimensions, four dimensions were suggested for the adapted scale: "forming an effective learning environment (FELE)," "designing the instructional process (DIP)," "technopedagogical competency (TPC)," and "understanding the learner (UL)."

The hypothesized model was tested and since the direct effect of TPC on FELE was found nonsignificant, it was removed from the model. That result suggests that the higher competency PTs have in techno-pedagogy, the more effectively they could build a learning environment by appropriately designing the instructional process. This finding coincides with studies that teachers should carry out effective educational activities through the use of technological equipments (Koh et al., 2013; Kumar et al., 2008). Furthermore, PTs should excel at necessary skills and knowledge by using technology in teaching (Hofer \& Swan, 2008) so that they can provide students with effective learning environments (Imbimbo \& Silvernail, 1999). However, Brown and Englehardt (2017) claim that PTs do not feel comfortable with integrating technology into teaching. Thus, the practical implication of this finding is to desing the teacher education process to enhance PTs' skills with technology, pedagogy, and content knowledge for effectively teaching. It is important to further emphasize that teachers should be able to establish their skills with technology in their field for improving teaching and learning experiences (Voogt, Fisser, Pareja Roblin, Tondeur, \& van Braak, 2013).

Furthermore, UL provided significant indirect and direct effects on FELE. That is, the better PTs could understand the learner, the more properly they could design the instructional process and ultimately form an effective learning environment. Teachers need understand the prejudgments of students and evaluate the level of their preparedness before learning activities start (NCATE, 2008). Furthermore, teachers should acquire the ability to relate all learning activities to students' experiences in a way that helps them learn (Eret, 2013). In line with these points, Jones et al. (2016) suggest that the active involvement of students in learning experiences is crucial to build effective conversion pedagogy to empower students. Otherwise, the teaching activities will not be probably successful if the notions of instructional designers and teachers do not serve to students' understanding (Doyle, 1977). Moreover, understanding the difficulties of the learner, establishing desire for learning through collaborative classroom environments, and the availability of a permissive pedagogy are vital issues for offering students with successful pedagogies (Lane \& Sharp, 2014). In doing so, teachers should be at the center of students social, as well as mental and emotional development (Bandura, 1969).

The findings of this study should be interpreted with caution due to several limitations. The first limitation is that the data using the scale of preparedness to teach were based on the self-assessment of participating PTs, which may include the participants' subjective ideas and perceptions, response bias, and responses constrained by fixed-choice items (Demetriou, Uzun Ozer, \& Essau, 2015). The second limitation is that the model based on the data obtained from 314 participants should be further verified based on PTs from other universities. The third limitation, due to being a cross-sectional survey design, can be supported by a longitudinal survey design. Thus, the causality in the model can be further checked based on changes in the students' thoughts about their preparedness to teach. The fourth limitation is that the findings can be compared to another study that obtains data from a more up-to-date scale. Additionally, the model can be justified by other measurement tools designed for these specific subscales. Nevertheless, studies based on experimental and mix-method designs can be carried out in the future for in-depth verification of the model. 


\section{Acknowledgements}

Research was conducted with approval from the Social and Behavioral Research Ethics Committee at Harran University. Participation was voluntary and anonymous. Informed consent was obtained from all participants. (Approval Number is 76244175-752.01.01).

\section{REFERENCES}

Bang, E., \& Luft, J. (2013). Secondary science teachers' use of technology in the classroom during their first 5 years. Journal of Digital Learning in Teacher Education, 29(4), 118-126. DOI: 10.1080/21532974.2013.10784715

Bandura, A. (1969). Principles of behavior modification. New York: Holt, Rinehart, and Winston.

Bentler, P. M. (1990). Comparative fit indexes in structural models. Psychological Bulletin, 107, 238-246. DOI: 10.1037/0033-2909.107.2.238

Bentler, P. M., \& Hu, P. (1995). EQS: Structural equations program manual. Los Angeles, CA: BMPD Statistical Software.

Brown, C. P., \& Englehardt, J. (2017). A case study of how a sample of preservice teachers made sense of incorporating iPads into their instruction with children. Journal of Early Childhood Teacher Education, 38(1), 19-38. DOI: 10.1080/10901027.2016.1274695

Browne, M. W. \& Cudeck, R. (1992). Alternative ways of assessing model fit. Sociological Methods \& Research, 21, 230-258. DOI: 10.1177/0049124192021002005

Bush, T. (2008). Leadership and management development in education. London: Sage.

Chai, C. S., Ng, E. M. W., Li, W., Hong, H., \& Koh, J. H. L. (2013). Validating and modelling technological pedagogical content knowledge framework among Asian preservice teachers. Australasian Journal of Educational Technology, 29, 41-53. DOI: 10.14742/ajet.174

Chen, F.-H., Looi, C.-K., \& Chen, W. (2009). Integrating technology in the classroom: a visual conceptualization of teachers' knowledge, goals and beliefs. Journal of Computer Assisted Learning, 25(5), 470-488. DOI: $10.1111 / \mathrm{j} .1365-2729.2009 .00323 . x$

Compton, V., \& Harwood, C. (2003). Enhancing technological practice: An assessment framework for technology education in New Zealand. International Journal of Technology and Design Education, 13(1), 1-26. DOI: 10.1023/A:1022318118467

Cook-Sather, A. (2003, March/April). Listening to students about learning differences. Teaching Exceptional Children, 22-26.

Darling-Hammond, L. (2006). Constructing 21st-century teacher education. Journal of Teacher Education, 57(3), 300-314. DOI: $10.1177 / 0022487105285962$

Darling-Hammond, L., Chung, R., \& Frelow, F. (2002). Variation in teacher preparation: How well do different pathways prepare teachers to teach? Journal of Teacher Education, 53(4), 286-302. DOI: $10.1177 / 0022487102053004002$

Demetriou, C., Uzun Ozer, B., \& Essau, C. A. (2015). Self-report questionnaires. In R. L. Cautin, and S. O. Lilienfeld (Eds.), The encyclopedia of clinical psychology (pp. 1-6). New York: JohnWiley \& Sons. DOI: 10.1002/9781118625392.wbecp50

Doyle, W. (1977). Paradigms for research on teacher effectiveness. In L. S. Schulman (Ed.), Review of research in education (pp. 163-197). Itasca: F.E. Peacock.

Eret, E. (2013). An assessment of pre-service teacher education in terms of preparing teacher candidates for teaching (Doctoral dissertation). Middle East Technical University, Ankara.

Hagger, H., Mutton, T., \& Bird, K. (2011). Surprising but not shocking: The reality of the first year of teaching. Cambridge Journal of Education, 41, 387-405. DOI: 10.1080/0305764X.2011.624999

Hanushek, E. A. (2011). The economic value of higher teacher quality. Economics of Education Review, 30(3), 466-479. DOI: $10.3386 / w 16606$

Harris, J., Mishra, P., \& Koehler, M. (2009). Teachers' technological pedagogical content knowledge and learning activity types: curriculum-based technology integration reframed. Journal of Research on Technology in Education, 41(4), 393-417. DOI: 10.1080/15391523.2009.10782536

Hattie, J. (2009). Visible learning: A synthesis of over 800 meta-analyses relating to achievement. London, UK: Routledge. DOI: 10.4324/9780203887332 
Hew, K. F., Lan, M., Tang, Y., Jia, C., \& Lo, C. K. (2019). Where is the "theory" within the field of educational technology research? British Journal of Educational Technology, 50(3), 956-971. DOI: 10.1111/bjet.12770

Hofer, M., \& Swan, K. O. (2008). Technological pedagogical content knowledge in action: A case study of a middle school digital documentary project. Journal of Research on Technology in Education, 41(2), 179200. DOI: $10.1080 / 15391523.2008 .10782528$

IBM Corp. (2013). IBM SPSS Statistics for Windows (Version 22.0). Armonk, NY: IBM Corp.

Imbimbo, J., \& Silvernail, D. (1999). Prepared to teach? Key findings of the New York City teacher survey. New York: New Visions for Public Schools.

Inan, F. A., \& Lowther, D. (2010). Laptops in the K-12 classrooms: exploring factors impacting instructional use. Computers \& Education, 55(3), 937-944. DOI: 10.1016/j.compedu.2010.04.004

Joiner, S., \& Edwards, J. (2008). Novice teachers: Where are they going and why don't they stay? Journal of Cross Disciplinary Perspectives in Education, 1, 36-43.

Jones, A., Olds, A., \& Lisciandro, J. (2016). Understanding the learner: Effective course design in the changing higher education space. International Studies in Widening Participation, 3(1), 19-35.

Kline, R. B. (2011). Principles and practice of structural equation modeling. Guilford press.

Knight, B. A., \& Moore, T. (2012). Supporting beginning male teachers as they transform to skilled professionals. Improving Schools, 15, 61-72.

Koehler, M. J., Mishra, P., \& Yahya, K. (2007). Tracing the development of teacher knowledge on a design seminar: Integrating content, pedagogy and technology. Computers \& Education, 49(3), 740-762. DOI: 10.1016/j.compedu.2005.11.012

Koh, J. L., Chai, C. S., \& Tsai, C. C. (2013). Examining practicing teachers' perceptions of technological pedagogical content knowledge (TPACK) pathways: A structural equation modeling approach. Instructional Science, 41, 793-809. DOI: 10.1007/s11251-012-9249-y

Kumar, N., Rose, R. C., \& D’Silva, J. L. (2008). Teachers' readiness to use technology in the classroom: An empirical study. European Journal of Scientific Research, 21(4), 603-616.

Kushner Benson, S. N., Ward, C. L., \& Liang, X. (2015). The essential role of pedagogical knowledge in technology integration for transformative teaching and learning, in Angeli C. and Valanides N. (Ed.), Technological pedagogical content knowledge exploring, developing, and assessing TPCK (pp. 3-18). New York: Springer Science + Business Media. DOI: 10.1007/978-1-4899-8080-9_1

Lane, J., \& Sharp, S. (2014). Pathways to success: Evaluating the use of "enabling pedagogies" in a university transition course. Journal on Education, 2(1), 66-73.

Liao, Y. C. (2007). Effects of computer-assisted instruction on students' achievement in Taiwan: A meta-analysis. Computers \& Education, 48(2), 216-233. DOI: 10.1016/j.compedu.2004.12.005

Lin, T., Tsai, C., Chai, C. S., \& Lee, M. (2013) Identifying science teachers' perceptions of technological pedagogical and content knowledge (TPACK). Journal of Science and Educational Technology, 22, 325336.

Mishra, P., \& Koehler, M. (2006). Technological pedagogical content knowledge: A framework for teacher knowledge. Teachers College Record, 108(6), 1017-1054. DOI: 10.1111/j.1467-9620.2006.00684.x

Muthén, L. K., \& Muthén, B. O. (2007). Mplus user's guide (Sixth Edition). Los Angeles, CA:Muthén \& Muthén.

Morrison, G. R., Ross, S. J., Morrison, J. R., \& Kalman, H. K. (2019). Designing effective instruction. John Wiley \& Sons.

National Council for Accreditation of Teacher Education (NCATE). (2008). Professional standards for the accreditation of schools, colleges, and departments of education. Washington, DC: Author.

Niess, M. L. (2005). Preparing teachers to teach science and mathematics with technology: Developing a technology pedagogical content knowledge. Teaching and Teacher Education, 21(5), 509-523. DOI: 10.1016/j.tate.2005.03.006

Nye, B., Konstantopoulos, S., \& Hedges, L. V. (2004). How large are teacher effects? Educational Evaluation and Policy Analysis, 26, 237-257. DOI: 10.3102/01623737026003237

Pillen, M., Beijaard, D., \& den Brok, P. (2013). Professional identity tensions of beginning teachers. Teachers and Teaching: Theory and Practice, 19, 660-678. DOI: 10.1080/13540602.2013.827455

Revell, A., \& Wainwright, E. (2009). What makes lectures 'unmissable'? Insights into teaching excellence and active learning. Journal of Geography in Higher Education, 33(2), 209-223. DOI: $10.1080 / 03098260802276771$

Rowan, B., Correnti, R., \& Miller, R. J. (2002). What large-scale, survey research tells us about teacher effects on student achievement: Insights from the prospects study of elementary schools. Teachers College Record, 104, 1525-1567.

Schmidt, D. A., Baran, E., Thompson, A. D., Mishra, P., Koehler, M. J., \& Shin, T. S. (2009) Technological pedagogical content knowledge (TPACK): The development and validation of an assessment instrument for preservice teachers. Journal of Research on Technology in Education, 42, 123-149. DOI: $10.1080 / 15391523.2009 .10782544$ 
Schunk, D. H., Pintrich, P. R., \& Meece, J. L. (2008). Motivation in education: Theory, research, and applications (3rd ed.). Upper Saddle River, NJ: Pearson Prentice Hall.

Senior, R. M. (2006). The experience of language teaching. Cambridge, England: Cambridge University Press.

Silvernail, D. L. (1998). Findings from an initial analysis of the New York City Teacher Survey. New York: New Visions for Public Schools.

Suhr, D. (2006). Exploratory or confirmatory factor analysis. SAS Users Group International Conference (pp. 1 17). Cary: SAS Institute, Inc. Retrieved from http://www2.sas.com/proceedings/sugi31/200-31.pdf

Ullman, J. B. (2001). Structural equation modeling. In B. G. Tabachnick \& L. S. Fidell (Eds.), Using multivariate statistics (4th Ed.). Needham Heights, MA: Allyn \& Bacon.

Voogt, J., Fisser, P., Pareja Roblin, N., Tondeur, J., \& van Braak, J. (2013). Technological pedagogical content knowledge-a review of the literature. Journal of Computer Assisted Learning, 29(2), 109-121. DOI: $10.1111 / \mathrm{j} .1365-2729.2012 .00487 . x$

West, S.G., Finch, J.F., \& Curran, P. J. (1995). Structural equation models with nonnormal variables: problems and remedies. In R.H. Hoyle (Ed.), Structural equation modeling: Concepts, issues and applications (pp. 56-75). Newbery Park, CA: Sage.

Wolff, C., van den Bogert, N., Jarodzka, H., \& Boshuizen, H. (2015). Keeping an eye on learning: Differences between expert and novice teachers' representations of classroom management events. Journal of Teacher Education, 66, 68-85. DOI: 10.1177/0022487114549810

Yildirim, I., \& Kalman, M. (2017). Öğretmenliğe hazır olma ölçeğinin Türkçe formunun geçerlik ve güvenirlik çalışması [The validity and reliability study of the Turkish version of the preparedness to teach scale]. Kastamonu Eğitim Dergisi, 25(6), 2311-2326. 


\section{APPENDIX 1}

Table 1.

Means, Standard Deviations, and Correlations of Item

\begin{tabular}{|c|c|c|c|c|c|c|c|c|c|c|c|c|c|c|c|c|c|c|c|c|c|}
\hline$J$ & M & SD & i1 & $\mathrm{i} 2$ & i3 & i4 & i5 & i6 & i7 & i8 & i9 & $\mathrm{i} 10$ & i11 & $\mathrm{i} 12$ & $\mathrm{i} 13$ & $\mathrm{i} 14$ & $\mathrm{i} 15$ & ii16 & i17 & i18 & ${ }_{\mathrm{i} 19}$ \\
\hline i1 & : & $\stackrel{n}{:}$ & & & & & & & & & & & & & & & & & & & \\
\hline i2 & $\stackrel{\sim}{\sim}$ & $\stackrel{\overbrace{}}{\longrightarrow}$ & $\overline{6}$ & & & & & & & & & & & & & & & & & & \\
\hline i3 & $\stackrel{\Re}{i}$ & $\stackrel{\Xi}{-}$ & मे & $\stackrel{\infty}{\stackrel{c}{c}}$ & & & & & & & & & & & & & & & & & \\
\hline i4 & $\infty_{\infty}^{\infty}$ & $\stackrel{\varrho}{=}$ & 㤐 & $\overrightarrow{\bar{n}}$ & $\hat{n}$ & & & & & & & & & & & & & & & & \\
\hline is & 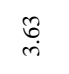 & $\stackrel{n}{=}$ & F & مٌ & 䒿 & క్రి & & & & & & & & & & & & & & & \\
\hline i6 & $\underset{\sim}{\infty}$ & $\stackrel{\bullet}{-}$ & 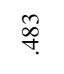 & bे & $\frac{n}{i n}$ & के & $\stackrel{+}{\oplus}$ & & & & & & & & & & & & & & \\
\hline i7 & $\underset{\infty}{\infty}$ & $\stackrel{\bullet}{-}$ & ळi & fa & : & $\overrightarrow{\ddot{n}}$ & $\stackrel{\infty}{\stackrel{\infty}{r}}$ & 菾 & & & & & & & & & & & & & \\
\hline i8 & $\underset{\infty}{\infty}$ & $\stackrel{9}{=}$ & $\bar{f}$ & 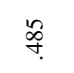 & for & fo & in & 苞 & 悉 & & & & & & & & & & & & \\
\hline i9 & 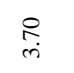 & $\stackrel{\infty}{\stackrel{-}{-}}$ & $\overline{\omega_{n}}$ & 寓 & $\overrightarrow{\mathrm{s}}$ & 员 & sog & ఫ్రి & $\stackrel{\infty}{?}$ & 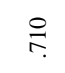 & & & & & & & & & & & \\
\hline i10 & $\underset{\sim}{\stackrel{D}{~}}$ & $\exists$ & F) & 。ํ. & . & 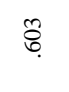 & مُ & : & مُ & : & ָৃ & & & & & & & & & & \\
\hline i11 & $\stackrel{\infty}{\infty}$ & $\stackrel{5}{:}$ & $\stackrel{\circ}{n !}$ & 志 & 常 & in & $\overline{6}$ & $\tilde{b}$ & $\bar{\alpha}$ & : & $\stackrel{\circ}{6}$ & $\stackrel{\infty}{\stackrel{\sim}{?}}$ & & & & & & & & & \\
\hline i12 & $\stackrel{8}{8}$ & $\stackrel{t}{\stackrel{t}{+}}$ & 总 & $\vec{\sigma}$ & : & 8 & $\stackrel{0}{0}$ & fo & : & 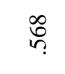 & 苦 & ह่ & 荧 & & & & & & & & \\
\hline i13 & हे & $\stackrel{\bullet}{:}$ & 字 & 冓 & $\overrightarrow{\bar{r}}$ & $\tilde{n}$ & $\%$ & $\stackrel{t}{0}$ & \%ّ & 管 & $\bar{\sigma}$ & : & 8 & 号 & & & & & & & \\
\hline i14 & $\underset{\mathrm{d}}{\mathrm{d}}$ & $\stackrel{n}{:}$ & $\vec{\alpha}$ & $\underset{v}{t}$ & $\bar{\sigma}$ & 䓴 & $\bar{\sigma}$ & f & 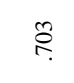 & 票 & कृ & : & $\stackrel{ \pm}{r}$ & $\stackrel{\infty}{\stackrel{\infty}{6}}$ & $\stackrel{\infty}{\stackrel{\infty}{\imath}}$ & & & & & & \\
\hline i15 & $\underset{\infty}{\infty}$ & $\stackrel{\infty}{\stackrel{-}{-}}$ & 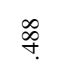 & 占 & $\begin{array}{l}\vec{\infty} \\
\overbrace{n}\end{array}$ & fr & 苞 & $\stackrel{\infty}{6}$ & ج & 承 & ర్రి & ఫ్రి & డ్రి & $\vec{\infty}$ & : & $\stackrel{\infty}{\stackrel{\infty}{.}}$ & & & & & \\
\hline i16 & Sా & $\stackrel{\overbrace{}}{\stackrel{S}{-}}$ & ๆे & 点 & $\begin{array}{l}\text { 莒 } \\
\text { "n }\end{array}$ & 守 & $\begin{array}{l}\infty \\
\substack{\infty \\
n}\end{array}$ & $\stackrel{\circ}{0}$ & జ్. & క్ర & $\widetilde{్ ర ్ ర ~}$ & . & 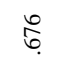 & $\begin{array}{l}\hat{\infty} \\
\text { n़े }\end{array}$ & : & $\stackrel{े}{~}$ & $\overline{\mathrm{\sigma}}$ & & & & \\
\hline i17 & 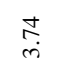 & $\stackrel{\circ}{=}$ & $\stackrel{\rho}{\rho}$ & 孛 & go & 守 & $\tilde{\hat{n}}$ & $\underset{f}{\stackrel{+}{f}}$ & 隽 & 吕 & $\overline{\mathrm{G}}$ & $\underset{\&}{\mathscr{\&}}$ & ơs & f. & 夺 & 号 & 是 & ถู & & & \\
\hline i18 & \&े & $\stackrel{\text { o }}{\rightarrow}$ & 荤 & : & 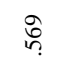 & $\stackrel{\infty}{\stackrel{\infty}{f}}$ & 守 & 今ั & 员 & م. & $\overrightarrow{\mathrm{\sigma}}$ & 足 & 古 & 苫 & हे & 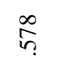 & 它 & : & 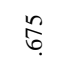 & & \\
\hline i19 & $\underset{\text { f }}{F}$ & 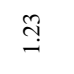 & 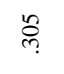 & हू & ఫे & ஓे & बे & $\bar{f}$ & 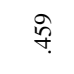 & $\frac{0}{n}$ & $\vec{\sigma}$ & 孛 & 字 & $\stackrel{\infty}{\stackrel{\infty}{~}}$ & $\stackrel{\infty}{\stackrel{\infty}{p}}$ & 㫭 & ఫे & $\stackrel{\text { \&̆ }}{\leftrightarrow}$ & in & 焉 & \\
\hline i20 & $\underset{\infty}{\infty}$ & $\stackrel{n}{=}$ & 号 & 夺 & n. & $\ddot{\sim}$ & $\stackrel{\infty}{6}$ & $\stackrel{\infty}{i n}$ & : & \&. & $\overline{\mathrm{G}}$ & مُ & $\tilde{\sigma}$ & $\stackrel{0}{i n}$ & 苦 & $\bar{\omega}$ & $\bar{b}_{n}$ & $\bar{\sigma}$ & iे & 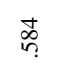 & fo \\
\hline
\end{tabular}




\section{TÜRKÇE GENIŞLETILMIŞ ÖZET}

Her zaman öğretmenlerin kalitesi ve okulların temel işlevi öğrenci başarısı için yüksek standartları belirleme noktasında tüm okul paydaşlarının en kritik ortaya çıkan taleplerinden biri olmuştur (Bush, 2008; Darling-Hammond, 2006). Birçok çalışma, diğer eğitim değişkenlerinin yanı sıra bir okulun öğretmenlerinin kalitesinin öğrenci başarısında en etkili değişken olduğunu göstermiştir (Hanushek, 2011; Hattie, 2009; Nye, Konstantopoulos ve Hedges, 2004; Rowan, Correnti ve Miller, 2002). Bu sonuçlar hem öğretmen adaylarının hem de öğretmenlerin sınıf içerisinde öğretmenlik için hazırlıklarının incelenmesine yol açmıştır. Özellikle, öğretmen adaylarının mesleğe geçişi, öğretmeyi beklediklerinden daha zorlayıcı bulabildikleri için bir belirsizliğe sahiptir (Joiner ve Edwards, 2008; Knight ve Moore, 2012; Pillen, Beijaard ve den Brok, 2013). Öğretmen adaylarının mesleğe başlamadan önce karşılaştıkları zorluklar iki kaynakla ilgilidir: gerçekçi öğretim kavramlarının ve öğrencileri ya da diğer paydaşların gerçekçi beklentilerinin olmamasıdır (Hagger, Mutton ve Bird, 2011).

Bahsedilen zorlukların yanı sıra diğer zorluklarla ilgili olarak, öğretime başlamadan önce öğretmen adaylarının çok yönlü becerileri Ulusal Öğretmen Eğitiminin Akreditasyonu Konseyi tarafından tanımlanmıştır (NCATE, 2008). Her şeyden önce, bu çalışma ile ilgili temel beceriler şunlardır: güçlü içerik bilgisine sahip olmak; içeriği yeterli bir şekilde sunmak; dersleri gerçek dünya örnekleriyle zenginleştirmek; uygun teknolojiyi kullanmak; öğrencilerin önyargılarını anlamak; deneyim ve araştırmaya dayalı öğretim ortamlarını tasarlanmak; kavramların öğrencilerin deneyimleriyle ilişkilendirmek; gerçek hayat konularının öğretimde uygulamak; okul başarısını artırmaya adamak; öğrencilerin başarı düzeylerini değerlendirmek; öğretim stratejisini öğrencilerin öğrenme yeteneğine göre ayarlamak; meslektaşları, aileleri ve diğer toplulukları bu sürece dahil etmek; ve destekleyici öğrenme ortamlarını tasarlanmaktır (Eret, 2013; NCATE, 2008).

Etkili öğrenme ortamları oluşturmak, etkili öğretimin en önemli bileşenidir. Ancak, öğrencilerin ihtiyaçları belirli noktalardan karşılanabiliyorsa bu durum ortaya çıkabilir. Bu noktalar öğrenciyi anlamak ve öğretim sürecini tasarlayarak tekno-pedagojide yetkinlik sergilemekten kaynaklanabilir. Bu nedenle bu çalışma, öğrenenleri anlamak ve tekno-pedagojide yetkinlik göstermek suretiyle öğretim sürecini tasarlayarak etkili öğrenme ortamlarının ne ölçüde oluşturulacağını anlamayı amaçlamaktadır.

$\mathrm{Bu}$ makalede sunulan araştırmanın temel amacı, öğreneni anlamanın ve tekno-pedagojik yetkinliğin etkili öğrenme ortamları oluşturma üzerindeki doğrudan ve dolaylı etkilerinin öğretim süreci tasarlanarak açıklanabileceği varsayım modelini incelemektir. Bu çalışma için varsayılan model Şekil 1'de sunulmaktadır. Özellikle, bu amaca yönelik araştırma soruları aşağıdaki gibidir:

(1) Öğreneni anlama, öğretim sürecini tasarlayarak öğrencinin etkili öğrenme ortamları oluşturmanın doğrudan ve dolaylı etkileri üzerinde ne ölçüde olabilir?

(2) Tekno-pedagojik yetkinlik, öğretim sürecini tasarlayarak etkili öğrenme ortamları oluşturmanın doğrudan ve dolaylı etkileri üzerinde ne ölçüde olabilir?

$\mathrm{Bu}$ araştırma soruları çerçevesinde, veriler Öğretime Hazır Olma Ölçeği ile toplanmış ve açımlayıcı faktör ve çoklu regresyon analizlerinin bir kombinasyonu olan Yapısal Eşitlik Modeli (YEM) ile analiz yapılmıştır (Ullman, 2001). Bu çalışma için "etkili öğrenme ortamı oluşturma" (EÖOO) noktasında "öğretim sürecini tasarlamak" (ÖST), "tekno-pedagojik yetkinlik" (TPY) ve "öğreneni anlama" (ÖA)'nın nedensel ilişkisi araştırılmıştır.

Bu çalışmada veri toplama aracı olarak Yıldırım ve Kalman (2017) tarafından Türkçe' ye uyarlanan Öğretmeye Hazır Olma ölçeği kullanılmıştır (Darling-Hammond vd., 2002; Silvernail, 1998). Orijinal 
ölçeğin beş boyutu olmasına rağmen, uyarlanmış ölçeğin dört boyutu vardır: "etkili öğrenme ortamı oluşturma", "öğretim sürecini tasarlama", "tekno-pedagojik yeterlilik" ve "öğreneni anlama".

Varsayılan model test edilmesi sonucunda, TPY'nin EÖOO üzerindeki doğrudan etkisi anlamlı bulunmadığı için direk etkisi modelden çıkarıldı. Bu sonuç, öğretmen adaylarının tekno-pedagojide ne kadar yüksek yetkinliğe sahip olmalarının, öğretim sürecini tasarlayarak daha etkili bir öğrenme ortamı oluşturabileceklerini göstermektedir. Bu bulgu, öğretmenlerin teknolojik ekipman kullanarak etkili eğitim faaliyetleri yürütmesi gerektiğini gösteren çalışmalarla örtüşmektedir (Koh vd. 2013; Kumar vd. 2008). Dahası, öğretmen adayları öğrencilere etkili öğrenme ortamları sağlayabilmeleri için öğretimde teknolojiyi kullanarak gerekli beceri ve bilgiye sahip olmalıdır (Imbimbo ve Silvernail, 1999).

Sonuçlara göre, ÖA, EÖOO üzerinde dolaylı ve doğrudan etkiler göstermiştir. Yani, öğretmen adayları öğreneni ne kadar iyi anlarsa, öğretim sürecini o kadar düzgün bir şekilde tasarlayabilir ve sonuçta etkili bir öğrenme ortamı oluşturabilirler. Öğretmenler, öğrenme etkinlikleri başlamadan önce öğrencilerin önyargılarını anlamalı ve hazır olma düzeylerini değerlendirmelidir (NCATE, 2008). Ayrıca, öğretmenlerin tüm öğrenme aktivitelerini öğrencilerin deneyimleriyle öğrenmelerine yardımcı olacak şekilde ilişkilendirebilmeleri gerekir (Eret, 2013). Bu noktalara paralel olarak, Jones vd. (2016) öğrencilerin öğrenme deneyimlerine aktif katılımının, öğrencileri güçlendirmek için etkili dönüşüm pedagojisi oluşturmak için çok önemli olduğunu öne sürmektedir.

$\mathrm{Bu}$ çalışmanın bulguları çeşitli sınırlamalar nedeniyle dikkatli bir şekilde yorumlanmalıdır. İlk sınırlama, öğretime hazır olma ölçeği kullanılarak toplanan verilerin, katılımcıların öznel fikirlerini ve algılarını içerebilen öz değerlendirmesine dayanmasıdır. İkinci sınırlama, 314 katılımcıdan elde edilen verilere dayanan modelin, diğer üniversitelerdeki öğretmen adaylarından elde edilecek verilere dayanılarak doğrulanması elde edilen modelin değerlendirilebilir. Kesitsel ölçek tasarımı olmakla ilgili üçüncü sınırlama, boylamsal bir ölçek tasarımı ile desteklenebilir. Böylece, modeldeki nedensellik, öğretmen adaylarının öğretmeye hazır olmalarına ilişkin düşüncelerindeki değişikliklere dayandırılarak daha ileri düzeyde kontrol edilebilir. Dördüncü sınırlama, bulguların daha güncel bir ölçekte veri elde eden başka bir çalışma ile karşılaştırılabilmesidir. Ek olarak, model bu alt ölçekler için tasarlanan diğer ölçüm araçlarıyla gerekçelendirilebilir. Bununla birlikte, modelin derinlemesine doğrulanması için deneysel ve karma yöntem tasarımlarına dayanan çalışmalar kullanılabilir. 